\title{
Distribution and hormonal regulation of membrane progesterone receptors $\beta$ and $\gamma$ in ciliated epithelial cells of mouse and human fallopian tubes
}

\author{
Magdalena Nutu${ }^{1}$, Birgitta Weijdegård ${ }^{1,2}$, Peter Thomas ${ }^{3}$, Ann Thurin- \\ Kjellberg ${ }^{2}$, Håkan Billig ${ }^{1}$ and DG Joakim Larsson*1
}

Address: ${ }^{1}$ Department of Neurosciences and Physiology, the Sahlgrenska Academy, University of Gothenburg, Box 434, SE-40530, Gothenburg, Sweden, ${ }^{2}$ Department of Obstretics and Gynecology, Sahlgrenska University Hospital, the Sahlgrenska Academy, University of Gothenburg, Blå Stråket 6, SE-41345, Gothenburg, Sweden and ${ }^{3}$ Marine Science Institute, University of Texas at Austin, 750 Channel View Drive, Port Aransas, TX 78373, USA

Email: Magdalena Nutu - magdalena.nutu@fysiologi.gu.se; Birgitta Weijdegård - birgitta.weijdegard@medfak.gu.se; Peter Thomas - peter.thomas@mail.utexas.edu; Ann Thurin-Kjellberg - ann.thurin@vgregion.se; Håkan Billig - hakan.billig@fysiologi.gu.se; DG Joakim Larsson* - joakim.larsson@fysiologi.gu.se

* Corresponding author

Published: 28 August 2009

Reproductive Biology and Endocrinology 2009, 7:89 doi:10.1186/1477-7827-7-89

This article is available from: http://www.rbej.com/content/7///89

(c) 2009 Nutu et al; licensee BioMed Central Ltd.

This is an Open Access article distributed under the terms of the Creative Commons Attribution License (http://creativecommons.org/licenses/by/2.0), which permits unrestricted use, distribution, and reproduction in any medium, provided the original work is properly cited.

\begin{abstract}
Background: The controlled beating of cilia of the fallopian tube plays an important role in facilitating the meeting of gametes and subsequently transporting the fertilized egg to its implantation site. Rapid effects of progesterone on ciliary beat frequency have been reported in the fallopian tubes of cows, but the identity of the receptors mediating this non-genomic action of progesterone is not known. We recently identified a member of the non-genomic membrane progesterone receptor family, mPR gamma, as a candidate for mediating these actions of progesterone. Here, we investigated the possible presence of a related receptor, mPR beta, in the fallopian tubes of mice and women as well as the possible hormonal regulation of $\mathrm{mPR}$ beta and gamma.
\end{abstract}

Methods: Western blot and immunohistochemistry with specific antibodies were used to characterize the expression and cellular localization of the mPRs in mouse and human tissues. Taqman (Quantitative Polymerase Chain Reaction) assays were used to quantify mRNA levels in the fallopian tubes of two different mouse models after injections with different hormones and specific antagonists.

Results: In the fallopian tubes of both mouse and human, the expression of mPR beta and mPR gamma proteins was exclusively found in the ciliated cells. Whereas mPR beta was found on the cilia, mPR gamma was localized at the base of the same ciliated cells, as previously reported. In gonadotropin-primed mice, both mPRs genes were down-regulated after an injection with progesterone. Treatment with estradiol rapidly down-regulated the level of $\mathrm{mPR}$ beta mRNA and protein in immature mice. The mPR gamma protein was down-regulated around the time of ovulation in cycling women, similar to the regulation observed in mice stimulated to ovulate via gonadotropin injections.

Conclusion: Our findings show the presence and hormonal regulation of two distinct mPRs associated with the cilia of the fallopian tubes in both mice and women. It is hypothesized that these receptors are involved in the control of ciliary movement and, thus, gamete transport in the fallopian tubes of mammals. 


\section{Background}

The fallopian tube (oviduct) of mammals consists mainly of muscular, ciliated and secretory cells. A central function of the fallopian tube is to facilitate gamete transport, fertilization and early embryonic development [1]. Gamete transport in the fallopian tube is reported to depend on both smooth muscle contractility and the action of cilia [2]. However, inhibition of muscle contractility by isoproterenol did not affect ovum transport in fallopian tube of rats [3], and much of the literature supports ciliary activity as the most important factor regulating gamete transport rate $[4,5]$. Sex steroids are involved in the control of gamete transport and ciliary activity in the fallopian tube. Estradiol $\left(\mathrm{E}_{2}\right)$ treatment accelerates ovum transport from $72 \mathrm{~h}$ to 24 hours in rats [6], facilitates sperm migration and induces adhesion of spermatozoa to the oviductal epithelium [7]. Concomitant treatment with progesterone $\left(\mathrm{P}_{4}\right)$ blocked $\mathrm{E}_{2}$-induced ovum transport [8], whereas $\mathrm{P}_{4}$ alone retarded the process [8-11]. Progesterone also acts directly on the sperm membrane to promote sperm motility $[12,13]$ and induces the acrosome reaction [14]. The cumulus cells surrounding the travelling ovum is a source for $\mathrm{P}_{4}$ in humans [15,16], rabbit [17], mouse [18] and pig [19]. It is possible that $P_{4}$ secreted from the oocyte cumulus complex acts as a beacon to the cilia of the fallopian tube, indicating its detailed position [20]. Indeed, understanding the underlying mechanism of $\mathrm{E}_{2}$ and $\mathrm{P}_{4}$ action in the regulation of tubal function is important.

Traditionally, $\mathrm{P}_{4}$ is thought to mediate its effects through its nuclear receptors, PGR-A and PGR-B, which are often co-expressed within the same cell $[21,22]$, to alter gene transcription. Not all effects of $\mathrm{P}_{4}$, however, can be explained by this classical mechanism of steroid action. It has been suggested that $\mathrm{P}_{4}$ together with PGR present in the cytoplasm could initiate a non-genomic signaling cascade [23]. Rapid responses to $\mathrm{P}_{4}$ have also been reported in tissues or cells naturally lacking nuclear PGR [24,25] and in Pgr knockout models [26], suggesting an involvement of other non-related receptors. [27]. A few years ago, a novel family of putative receptors (mPRs), including $\mathrm{mPR} \alpha, \beta$ and $\gamma$, were identified $[28,29]$. The mPRs belong to the Class II progestin and adipoQ receptors family (PAQR) [30,31]. There is a growing set of data, to suggest a supporting role of the mPRs as functional progestin receptors in different vertebrates, although there are still some controversies about their function [32-35]. The best described forms are the mPR $\alpha$ and mPR $\beta$ proteins $[33,35-$ $42]$, whereas mPR $\gamma$ is less studied $[20,28,30]$.

We have previously shown that mPR $\gamma$ is expressed at the apical cell membrane of ciliated cells in the mouse and human fallopian tube, leading us to hypothesize that mPR $\gamma$ can be a mediator of rapid effects of $\mathrm{P}_{4}$ on ciliary activity in mammals [20]. Monkkonen et al. (2007) reported the expression of the mPR $\beta$ gene in a fallopian tube cell line possessing secretory epithelial cell properties [39], and Romero-Sanchéz et al. (2008) reported expression of the mPR $\beta$ and $\alpha$ protein in all epithelial cells of the human fallopian tube, but the intracellular localization of the receptors remained unclear [43]. In this study we demonstrate a distinct membrane-associated localization of both $\mathrm{mPR} \beta$ and $\gamma$ in ciliated cells of the fallopian tube in mice and women. Whereas mPR $\gamma$ is found at the base of the cilia, mPR $\beta$ is located along the cilia themselves. Furthermore, we show regulation of both $\mathrm{mPR} \beta$ and $\gamma$ by sex steroid treatment in mice and a variable mPR $\beta$ expression in fallopian tubes of women during the menstrual cycle. Our results suggest the possibility for a cooperative role of $\operatorname{mPR} \beta$ and $\gamma$ in gamete transport.

\section{Methods \\ Antibodies, hormones and reagents}

For Western blot analysis and immunohistochemistry studies, the following primary and secondary antibodies were used: $\operatorname{mPR} \beta$ [44], mPR $\gamma[20], \beta$ tubulin-IV (T7941; SigmaAldrich, St Louis, MO), PGR (sc-539; C-20; Santa Cruz Biotechnologies Inc, Santa Cruz, CA) and FSHr (sc-7798; N-20; Santa Cruz Biotechnologies Inc). The alkaline phosphatase anti-rabbit IgG (T2191; Tropix, Bedford, MA), alkaline phosphatase anti-goat IgG (SC-2022; Santa Cruz Biotechnologies Inc), TexasRed anti-rabbit IgG (TI-1000, Vector lab Inc., Burligame, CA) and TexasRed anti-mouse IgG (TI 2020; Vector lab Inc.) were used as secondary antibodies.

Progesterone $\left(\mathrm{P}_{4}\right)$ and 17- $\beta$-estradiol $\left(\mathrm{E}_{2}\right)$ were from Sigma; ICI 182,780 (Faslodex ${ }^{\mathrm{TM}}$, AstraZeneca) was purchased from Tocris Cookson Ltd. (Bristol, UK), and CDB2914 was from Organon (N.V. Organon, Oss, and Netherlands). Equine gonadotropin (eCG; cat.no.G4877) was from Sigma-Aldrich (Saint Louis, MO), and human chorionic gonadotropin (hCG) was obtained from N.V. Organon. The protease inhibitor cocktail was from Roche Diagnostics (Roche Complete, Mannheim, Germany), and CDP-Star ready-to-use developing system was from Tropix. All chemicals used in immunohistochemistry or immunofluorescent staining, included in kits or alone, were purchased from Vector Laboratories, Inc., unless otherwise specified.

\section{Animal studies}

All experiments were performed with the approval of the annual local ethics committee in Gothenburg, Sweden (246/2007 to D.G.J. Larsson). The animals, 352 females and three males C57BL/ 6 mice, used in these experiments were obtained from Taconic M\&B, Copenhagen, Denmark.

\section{Experimental design and tissue preparation in mice} Tissue distribution of $m P R \beta$ in male and female mice

To examine the general tissue distribution of $\mathrm{mPR} \beta$, different organs from immature (21-day-old) male and female mice ( $\mathrm{n}=3$ biological replicates per sex), were col- 
lected. Fat or connective tissues were immediately removed from the tissues, and the samples were directly frozen in liquid nitrogen for protein preparation and Western blot analysis (see below for details).

Localization of $m P R \beta$ and $\gamma$ proteins in the mouse fallopian tube To investigate the localization of mPRs in the fallopian tube, tissues from immature female mice (21-day-old) were collected and fixed in 10\% neutral buffered formalin for immunohistochemistry analysis.

Regulation of $m P R \beta$ and $\gamma$ in the fallopian tube of immature female mouse following hormonal treatment

The concentrations of $\mathrm{E}_{2}$ and $\mathrm{P}_{4}$ are very low in the immature mouse, allowing us to assess the effects of exogenous steroid addition with limited interference by endogenous steroids. To examine whether exogenous $\mathrm{E}_{2}$ and $\mathrm{P}_{4}$ regulate $\mathrm{mPR} \beta$ and $\gamma$ expression, individual groups of 21-dayold female mice were therefore given one i.p. injection $\mathrm{E}_{2}$ $(0.3 \mathrm{mg} / \mathrm{kg})$ or $\mathrm{P}_{4}(4 \mathrm{mg} / \mathrm{kg})$. To investigate whether the nuclear estrogen receptors (ESRs) and PGRs are involved in the regulation of $\mathrm{MPR}$, we used the ESR antagonist ICI 182,780 (ICI, $8.3 \mathrm{mg} / \mathrm{kg}$ ) and the PGR-A/B antagonist CDB2914 (CDB, $1 \mathrm{mg} /$ animal). All compounds were suspended in $100 \mu \mathrm{l}$ of sesame oil (Sigma). After $2 \mathrm{~h}$ and $6 \mathrm{~h}$ of treatment, one group of animals $(n=5)$ was killed, and the tissues were frozen immediately for RNA preparation. To study the regulation of the $\mathrm{mPR}$ proteins, fallopian tubes were sampled $6 \mathrm{~h}$ and $24 \mathrm{~h}$ after injection with either $\mathrm{E}_{2}$ or oil and were frozen in liquid nitrogen for Western blot analysis. Whereas RNA analyses were performed on individual samples, pooling of tissue from ten individual mice was required for each protein analysis. Thus, the experiment with $\mathrm{E}_{2}$ and oil was repeated several times to generate three independent pools of tissue from each treatment group for the analyses of $\operatorname{mPR} \beta$ and $\gamma$.

Regulation of $m P R \beta$ and $\gamma$ in eCG-stimulated female mouse fallopian tube following hormonal treatment

In the mouse, the levels of expression of PGR and ESR are increased after hormonal treatment [45-47]. Therefore, to verify the effect of steroid treatment in a model expected to have higher levels of nuclear receptors, as well as being closer to a developmental stage when the control of gamete transport becomes important, we also used a gonadotropin-primed mouse model. Immature female mice (21day-old) were given a single i.p. injection of 5 IU equine Chorionic Gonadotropin (eCG). After 48 h, the mice were injected i.p. with the steroid/antagonist and were sampled after $2 \mathrm{~h}$ or $6 \mathrm{~h}$, as described under experiment three.

\section{Effects of gonadotropins on $m P R \beta$ and $\gamma$ expression in mouse fallopian tube}

To study the regulation of $\operatorname{mPR} \beta$ and $\gamma$ before and after ovulation and to allow a comparison with human data (see below), we used a mouse model where eCG was administered as in experiment four. After $48 \mathrm{~h}$, mice were injected i.p. with 5 IU of human Chorionic Gonadotropin (hCG). In mice given this treatment, serum $\mathrm{E}_{2}$ concentrations are increased by $24 \mathrm{~h}$ after eCG administration, reaching a peak after $48 \mathrm{~h}$, whereas $\mathrm{P}_{4}$ concentration are increased after post-hCG administration and peak around $48 \mathrm{~h} \mathrm{[46]}$. The serum levels of $\mathrm{E}_{2}$ and $\mathrm{P}_{4}$ in immature mice upon treatment with eCG/hCG is similar to those of adult cyclic mice [48]. At times 0, 48, 72 and $96 \mathrm{~h}$ from the onset of the first injection, animals were killed by cervical dislocation, and their fallopian tubes were dissected and frozen in liquid nitrogen for Western blot analysis.

\section{Human studies}

Fallopian tube samples were obtained from 12 fertile women, aged $2842 \mathrm{y}$, undergoing tubal ligations at the Sahlgrenska University Hospital. Prior to the operation, informed consent from the patients and approval by the institutional committee on the use of human subjects in Gothenburg (RS175-99 to A. Thurin) were obtained. All women had a clinical examination before surgery and had regular menstrual cycles (cycle length, 2532 days). No woman had used hormonal medication within three months of surgery. The menstrual phase of each patient at the day of operation was classified based on previous menstrual history, serum steroids and luteinizing hormone-levels in urine [49]. A cross-section of the isthmus part of the fallopian tube was taken from each patient. One part was fixed with $10 \%$ neutral buffered formalin, embedded in paraffin, sectioned and mounted. The remainder was placed into cold saline solution prior to freezing $\left(-70^{\circ} \mathrm{C}\right)$ for later Western blot analyses.

\section{RNA isolation and reverse transcription-polymerase chain reaction}

Total cellular RNA was isolated from the fallopian tubes of individual mice using the RNeasy Micro Kit (Qiagen, Germany) according to the manufacturer's instructions and was treated with an RNase inhibitor (Applied Biosystems, Foster City, CA). A single batch of $0.5 \mu \mathrm{g}$ of total RNA from each sample was used to synthesize singlestranded cDNA using High-Capacity cDNA Reverse Transcription Kits (Applied Biosystems). Primers targeting the cDNA sequence of mPR $\beta$ (sense, 5'-CGGCGGCTGCTTTCTGT-3' and antisense, 5'-TAAGGCCGTCGGTAGCGATA-'3), mPR $\gamma$ (sense, 5'-CTCCCTAGGCTATTCC GCATAG-3' and antisense, 5'-GGATGCCCTGCTCATGGA-3') and GAPDH, used as an endogenous control (sense, 5'-TGTGTCCGTCGTGGATCTGA-3' and antisense, 5'-ATGCCTGCTTCACCACCTTCT-3') were designed by using Primer Express (Applied Biosystems) and purchased from Cybergene AB, Stockholm, Sweden. The corresponding cDNA fragments were denatured at $98^{\circ} \mathrm{C}$ for $2 \mathrm{~min}$, annealed at $59^{\circ} \mathrm{C}$ for $30 \mathrm{sec}$. The number of RT-PCR cycles was chosen to generate detectable signals without approaching saturation in any samples. After 30 cycles of 
amplification, the PCR products were isolated by electrophoresis and visualized using ethidium bromide.

\section{Taqman quantitative polymerase chain reaction}

The Taqman QPCR reaction (quantitative polymerase chain reaction) was performed with the ABI Prism 7000 Sequence Detector (Applied Biosystems). The dissociation graph showed only one specific amplicon product for each target. For each amplification reaction, $20 \mathrm{ng}$ cDNA, $500 \mathrm{nM}$ of each primer and $1 \times$ Sybr $^{\circledR}$ Green PCR reaction mix (Applied Biosystems) was combined into a final volume of $25 \mu$ l. The PCR parameters were set according to the manufacturer's protocol. All reactions were performed in duplicate for both target genes and endogenous controls. The efficiencies of target and the endogenous controls were similar. Because not all samples could be run at the same time, one standard sample was run five times as duplicates in all assays to compensate for possible run to run variations. The expression of each target gene was normalized to the endogenous control (GAPDH) by subtracting the CT-value from the target gene with the CT-value of the endogenous control. To compare levels relative to a calibrator (mean of Group 1), $\Delta$ CT of group 1 was subtracted from the $\Delta \mathrm{CT}$ of each sample. Relative expression is given by $2-\Delta \Delta \mathrm{Ct}$.

\section{Protein extracts and Western blot analysis}

All protein preparations of fallopian tube samples were performed as described by Fujii et al., (2001) [50]. Samples from male and female mice used in the tissue distribution experiment were prepared according to Bordier et al. (1981) and Nutu et al., (2007). Thirty $\mu \mathrm{g}$ of protein were run by electrophoresis on $412 \%$ one-dimensional Bis-Tris gels (Novex, San Diego, CA, USA). In experiments in which both $\operatorname{mPR} \beta$ (1:5000), mPR $\gamma$ (1:100), PGR $(1: 250)$ and follicle stimulating hormone receptor (FSHr; $1: 250)$ were assessed, the gels were cut into two pieces along a line corresponding to approximately $60 \mathrm{kDa}$. The section containing higher molecular weights was exposed to antibodies against PGR, or FSHr, and the lower molecular weight section was exposed to antibodies against $\operatorname{mPR} \beta$ or $\gamma$. Separate gels and membranes were run for the two mPRs as they have very similar molecular masses. The immunosignal-CDP-Star ready-to-use substrate for the alkaline phosphatase system (Tropix, Bedford, MA, USA) was used to visualize protein bands. Immunoblotted signals were quantified by densitometry using the Quantity One Software package (version 4.2, BioRad, Hercules, CA) directly after detection in a Fluor-S multi-imager (Bio-Rad Laboratories, Sundbyberg, Sweden). The loading was evaluated by staining the gels with Coomassie blue. Signal intensities of the individual protein were normalized to the gels stained with Coomassie blue and presented as ratios that represent arbitrary densitometric units (ADU) of relative abundance.

\section{Immunohistochemical analysis and confocal microscopy}

Single and dual-fluorescence immunohistochemistry were based on the previously described methodology [20]. Approximately $4 \mu \mathrm{m}$ thick tissue sections were placed on glass slides, deparaffinized, rinsed in ethanol and re-hydrated through a series of decreasing concentrations of ethanol. Antigens were retrieved by boiling with an antigen unmasking solution for $20 \mathrm{~min}$ at $120^{\circ} \mathrm{C}$, which was followed by cooling in $\mathrm{dH}_{2} \mathrm{O}$ for $5 \mathrm{~min}$. Nonspecific binding was blocked with the background sniper (Biocare medical, Concord, CA USA), for $10 \mathrm{~min}$ at a room temperature. The sections were incubated in a humidified chamber at $4^{\circ} \mathrm{C}$ over night, with either a polyclonal antibody against $\operatorname{mPR} \beta$ at dilution of $1: 600$ or a mouse monoclonal anti- $\beta$-tubulin IV mouse at a dilution of 1:600 in TBS. The MACH 3 rabbit AP (alkaline phosphatase) polymer kit and MACH 3 mouse HRP (horse radish peroxidase) polymer kit (Biocare Medical) were used as the detection systems, and the immunostaining was visualized by using Vulcan Fast Red Chromagen Kit and Romulin AEC Chromagen Kit (Biocare Medical) according to the manufacturer's protocol. Sections were counter stained with hematoxylin, dehydrated through a series of increasing concentrations of ethanol to clear the tissue and cover-slipped. The immunostaining and detection of $\mathrm{mPR} \gamma$ protein were performed using the same protocol as previously reported [20]. Negative control slides were prepared in an identical manner and processed with a ready-to-use mouse or rabbit IgG negative control (Biocare Medical) instead of the primary antibody. Slides were viewed on a Nikon EFD-3 (Nikon, Tokyo, Japan) microscope under bright field optics and photographed. The immunofluorescences on the slides were viewed on an Axiovert 200 confocal microscope (Carl Zeiss, Jena, Germany) equipped with a laser-scanning confocal imaging LSM 510 META system (Carl Zeiss) and was photomicrographed. Background settings were adjusted from examination of negative control specimens. Images of positive staining were adjusted to make the optimal use of the dynamic range of detection. Figures were composed in Adobe Photoshop with minimal alteration for presentation and layout.

\section{Statistical analysis}

Data were analyzed using Minitab ${ }^{\circledR}$ Statistical Software (Minitab Ltd., Coventry, UK). Differences between group means were analyzed using the general linear model (GLM). Post-hoc tests was applied were appropriate, including Dunnet's test for multiple comparisons to a control group or Bonferroni's test for comparisons between all groups. Residual analyses were used to check assumptions of normality and equality of variances and log-transformed when appropriate. Data are presented as mean \pm SEM. P-values $<0.05$ were considered statistically significant. 


\section{Results}

Tissue distribution of $m P R \beta$ in male and female mice

We previously reported the tissue distribution of $\mathrm{mPR} \gamma$ in male and female mice [20]. [46]To determine the distribution of mPR $\beta$ protein in the same model, Western blot analysis was performed using a well-characterized antibody. The expression of mPR $\beta$ protein was confirmed by a single band of $40 \mathrm{kDa}$ in female reproductive tissues (ovary, fallopian tube and uterus). High expression of $\mathrm{mPR} \beta$ was also detected in male testis, whereas lower levels were observed in other tissues of both sexes (Fig. 1). The liver and kidney of both male and female mice showed the lowest, but still detectable, levels of mPR $\beta$.

\section{Localization of $m P R \beta$ and $m P R \gamma$ proteins in the mouse fallopian tube}

The mPR $\beta$ protein was expressed in the fallopian tube of immature female mice (Fig. 2A). The localization was confirmed by immunohistochemistry (2A.a and d) and immunofluorescence (2A. g, i and j). The mPR $\beta$ was only found in the cilia of epithelial cells facing the lumen of the fallopian tube (c, d, f, and g). The identity of the cell type expressing mPR $\beta$ was verified using $\beta$-tubulin IV, a specific marker for ciliated cells (2A. b, e and h). Confocal microscopy also showed co-localization of $\mathrm{mPR} \beta$ (green) and $\beta$-tubulin (red) immunoreactivity (2A. i and j). The localization of $\mathrm{mPR} \beta$ was restricted to the upper part of the epithelial cell cilia (2B.a), whereas $\mathrm{mPR} \gamma$ was associated with the apical membrane of the cells (2B. b1) as previously reported [20]. These results were also confirmed using immunohistochemistry (2B.b1) and dual immunofluorescence (2B.b2). Labeling with an antibody against $\beta$-tubulin IV showed a strong staining restricted to the cilia of epithelial cells (2B.c).

\section{Regulation of $m P R \beta$ and $m P R \gamma$ in the fallopian tube of immature female mouse following hormonal treatment}

Considering that fallopian tubes from multiple mice are required for each Western blot analysis of $\mathrm{mPR}$ protein, we decided to first study the regulation of receptors on the

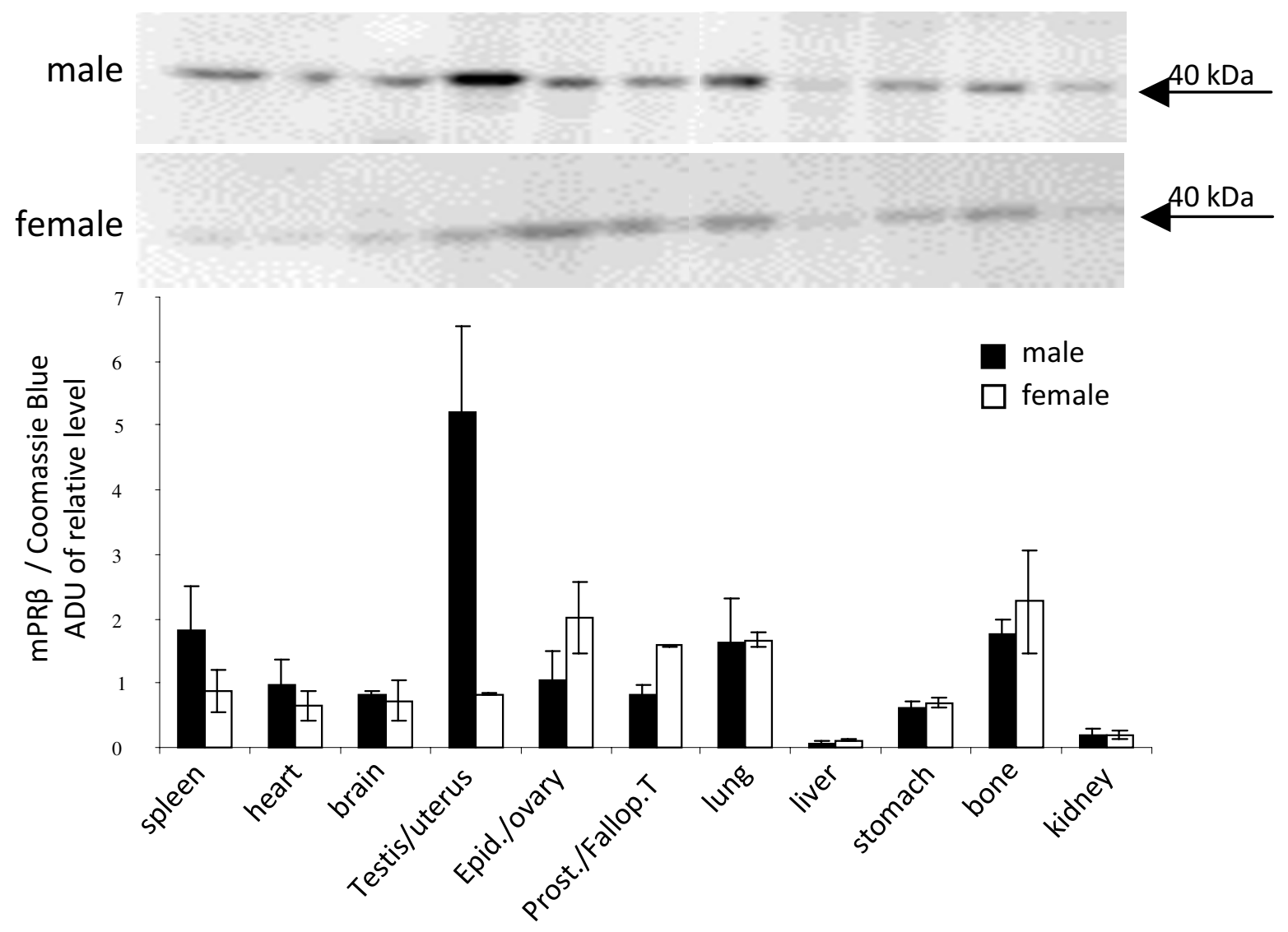

Figure I

Western blot analysis of $\mathrm{mPR} \beta$ in tissues of male and female mice. Densitometric quantification is indicated by the bar graph. Data are presented as mean arbitrary density units normalized to total protein loading \pm SEM from three biological replicates per tissue. 

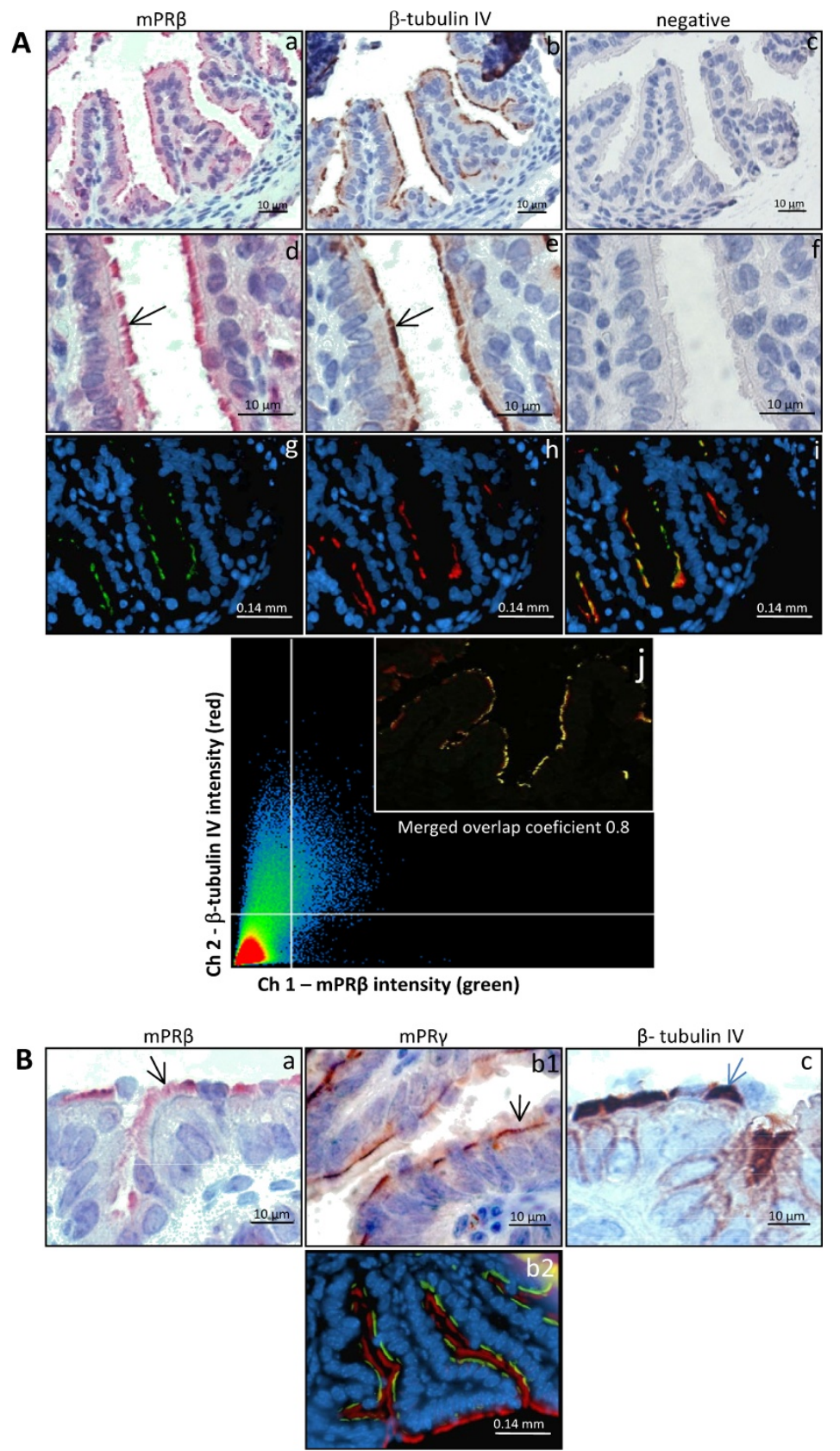

\section{Figure 2}

Immunostaining for $\mathbf{m P R} \beta, \mathbf{m P R} \gamma$ and $\beta$-tubulin proteins in the mouse fallopian tube. A: Immunohistochemical (a f) and immunofluorescent $(\mathbf{g} \mathbf{j})$ detection of $\mathrm{mPR} \beta$ and $\beta$-tubulin, a marker for ciliated epithelial cells. Sections immunolabeled for $\mathrm{mPR} \beta$ were visualized with MACH 3 rabbit AP (a and $\mathbf{d})$ and green florescence $(\mathbf{g})$. The $\beta$-tubulin was stained with MACH 3 mouse HRP ( $b$ and $\mathbf{e}$ ) and red fluorescence (h). The panels' $\mathbf{c}$ and $\mathbf{f}$ are control sections where the primary antibody was omitted. A double staining was also performed using green and red fluorescent labels for mPR $\beta$ and $\beta$-tubulin, respectively (i). All fluorescence sections were subsequently counterstained with DAPI to visualized cell nuclei. Confocal microscopy in (j) is showing the overlapping fluorescence of two fluorochromes used. Tubal sections were labelled for mPR $\beta$ (green), $\beta$-tubulin (red) and merged (yellow). 2B: To facilitate a comparison of the localization of the mPRs, immunostaining for mPR $\beta$ (a) mPR $\gamma$ (b I) $\beta$-tubulin (c) and dual staining of mPR $\gamma$ (green) and $\beta$-tubulin (red) (b2) are also presented. 
mRNA level. As indicated in Fig. 3A, RT-PCR confirmed the expression of both mPR $\beta$ mRNA and mPR $\gamma$ mRNA in immature mice.

Exposure to $\mathrm{E}_{2}$ rapidly and significantly decreased the mRNA expression of mPR $\beta$ but not of mPR $\gamma$, which had an opposite trend (Fig. 3B). The decrease in mPR $\beta$ mRNA was reflected in a similar decrease in protein levels (Fig. $3 \mathrm{C})$. There were no significant effects of $\mathrm{P}_{4}, \mathrm{ICI}$ or CDB on either $\mathrm{mPR} \beta$ and $\mathrm{mPR} \gamma$ gene expression two or six hours post injection (Fig. 3B). The standard deviations (SD) between the run to run samples were 0.008 cycles for the $2 \mathrm{~h}$ samples and 0.045 cycles for the $6 \mathrm{~h}$ samples and did not significantly affect the results; thus, no run-to-run compensation was included in the final calculations.

\section{Regulation of $m P R \beta$ and $m P R \gamma$ in eCG-stimulated female mouse fallopian tube following hormonal treatment}

In the eCG-primed female mouse, $\mathrm{E}_{2}$ treatment did not cause a significant decrease in the expression of $\mathrm{mPR} \beta$ mRNA at two hours, similarly to its effects in the immature mouse model. In contrast to the immature model, $\mathrm{P}_{4}$ treatment significantly down-regulated expression of $\operatorname{mPR} \beta$ at this time (two hours). The mPR $\gamma$ expression was also significantly reduced by $\mathrm{P}_{4}$ (six hours), whereas no effects where observed with the injections of $E_{2}$, ICI or CDB (Fig. 4).

\section{Effects of gonadotropins on $m P R \beta$ and $m P R \gamma$ expression in mouse fallopian tube}

Treatment of immature mice with eCG did not affect the expression of the mPR proteins $48 \mathrm{~h}$ post injection. An additional injection with hCG transiently reduced the expression of mPR $\gamma$ protein after $24 \mathrm{~h}$, whereas the expression of $\mathrm{mPR} \beta$ remained unaffected (Fig. 5).

\section{Expression of $m P R \beta$ and $m P R \gamma$ in fallopian tubes from cycling women}

Similar to the localization in mice, human $\operatorname{mPR} \beta$ was found in the distal part of the cilia of epithelial cells (Fig. $6 \mathrm{~A} ; \mathrm{a}, \mathrm{b})$, whereas $\mathrm{mPR} \gamma$ was associated with the apical membrane of ciliated epithelial cells (Fig. 6A; d, e). Western blotting of human fallopian tubes also demonstrated expression of both $\mathrm{mPR} \beta$ and $\mathrm{mPR} \gamma$ proteins with molecular weights of about $40 \mathrm{kDa}$ (Fig. 6B). The expression of mPR $\gamma$ in women sampled around ovulation was significantly lower than the expression in preovulatory women (Fig. 6B).

\section{Discussion}

This study demonstrates a specific expression of mPR $\beta$ and mPR $\gamma$ proteins in ciliary cells of both mouse and human fallopian tube epithelia. In contrast to earlier reports [43], we show a distinct expression of $\operatorname{mPR} \beta$ on the cilia proper and of $\operatorname{mPR} \gamma$ at the base of the same cilia.
We hypothesize that $\mathrm{mPR} \beta$ and $\mathrm{mPR} \gamma$ have cooperative, but still distinctive functions in controlling ciliary movement and, thus, gamete transport in the fallopian tube of mammals. A demonstrated down-regulation of both mPRs after exogenous $\mathrm{P}_{4}$ treatment adds support to the previously proposed roles of the mPRs as functional $\mathrm{P}_{4}$ receptors $[12,29]$

We previously reported a detailed tissue distribution of $\mathrm{mPR} \gamma$ in male and female mice [20]. In the present study, we show that the mPR $\beta$ protein is expressed in reproductive tissues such as fallopian tube, ovary and testis of both male and female mice. In other species, including human, pig, rat and fish, the expression of mPR $\beta$ has been reported not only in reproductive tissues, but in nonreproductive tissues as well, including brain, heart and liver $[29,31,34,36,38,40,44]$. This was also the case in the mouse; however, the relative expression level of mPR $\beta$ between different organs appears to vary between species. The mPR $\beta$ appears to be expressed more evenly between tissues compared with $\mathrm{mPR} \gamma$. In contrast to the high expression level of $\mathrm{mPR} \gamma$ in liver, $\mathrm{MPR} \beta$ was almost undetectable in this organ. There were no marked differences in expression between the sexes for $\operatorname{mPR} \beta$, except for the reproductive tissues. We did not find a particularly high level of $\operatorname{mPR} \beta$ expression in the brain, as previously reported [29,34]; however, this may be because we only studied the general tissue distribution in pre-pubertal animals.

Membrane progesterone receptor $\beta$ was found in the motile cilia of epithelial cells in fallopian tube of both mice and women. The co-localization of $\operatorname{mPR} \beta$ and $\beta$ tubulin IV, a cellular marker for cilia, also confirms the specific localization. In contrast, Romero-Sánchez et al. (2008) reported immunostaining of all epithelial cells, including both secretory and ciliated cells, in the human fallopian tube using the same $\operatorname{mPR} \beta$ antibody as in our study. However, the localization within these cell types was unclear [43]. We have experienced that different fixation and staining techniques can give rise to a rather general intracellular staining using this and other antibodies (unpublished data). Qui et al. (2008) also show that the staining technique can be crucial, as addition of Triton $\mathrm{X} 100$ switched the staining by another antibody against mPR $\beta$ from the plasma membrane to a general intracellular staining in porcine cumulus cells [40]. Therefore, it is important to optimize the protocol to achieve the most specific staining possible. Several other studies, which used the same antibody used in the present study, report a plasma membrane localization of $\operatorname{mPR} \beta$ in different cells and species, including human myocytes [33], human T lymphocytes and Jurkat cells [51] and mouse gonadotropes [52]. Other studies report an intracellular localization of $\operatorname{mPR} \beta$ and $\gamma$, possibly in the endoplasmic 

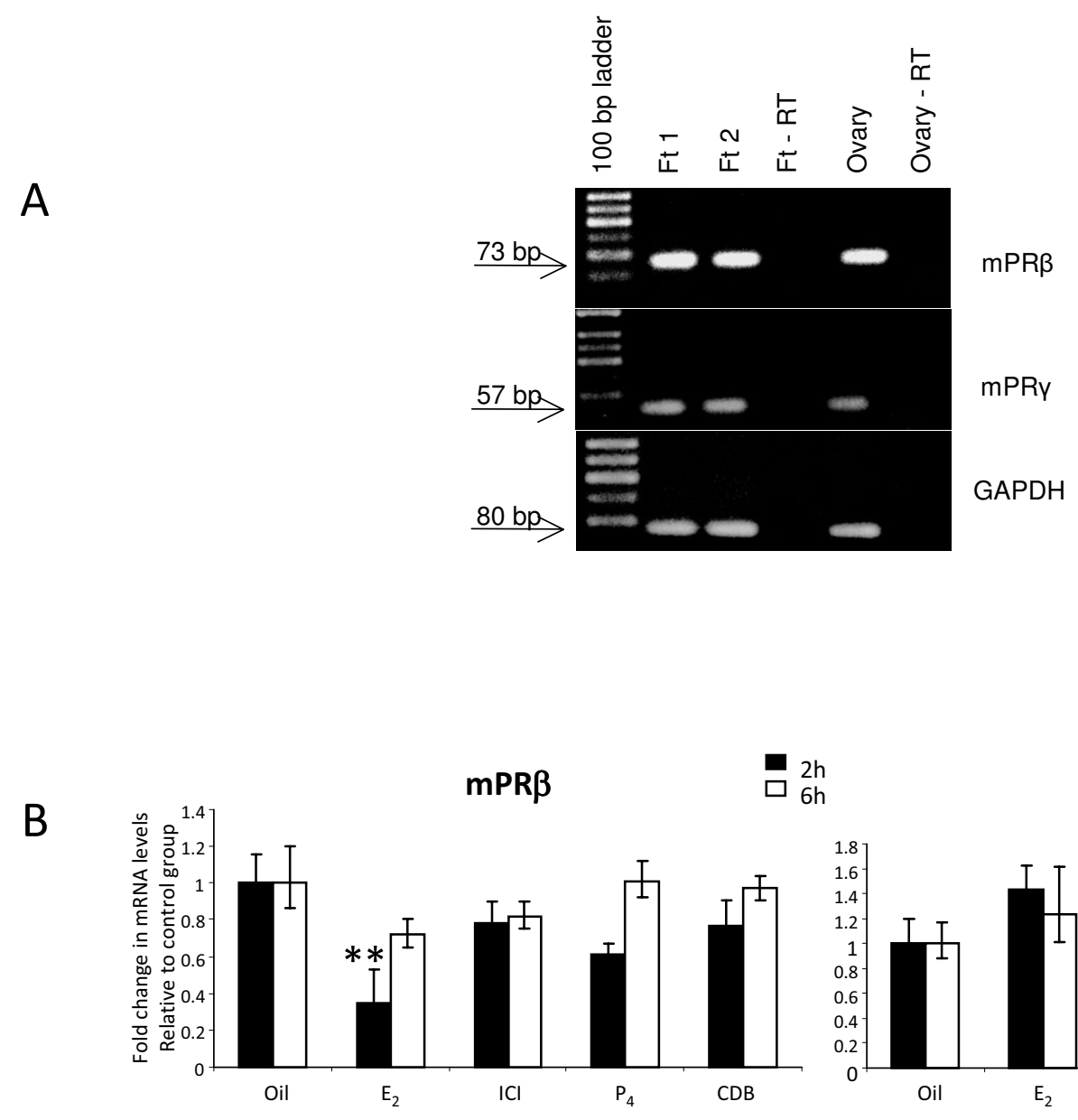

$\square_{6 \mathrm{~h}}^{2 \mathrm{~h}} \quad \operatorname{mPR} \boldsymbol{P}$
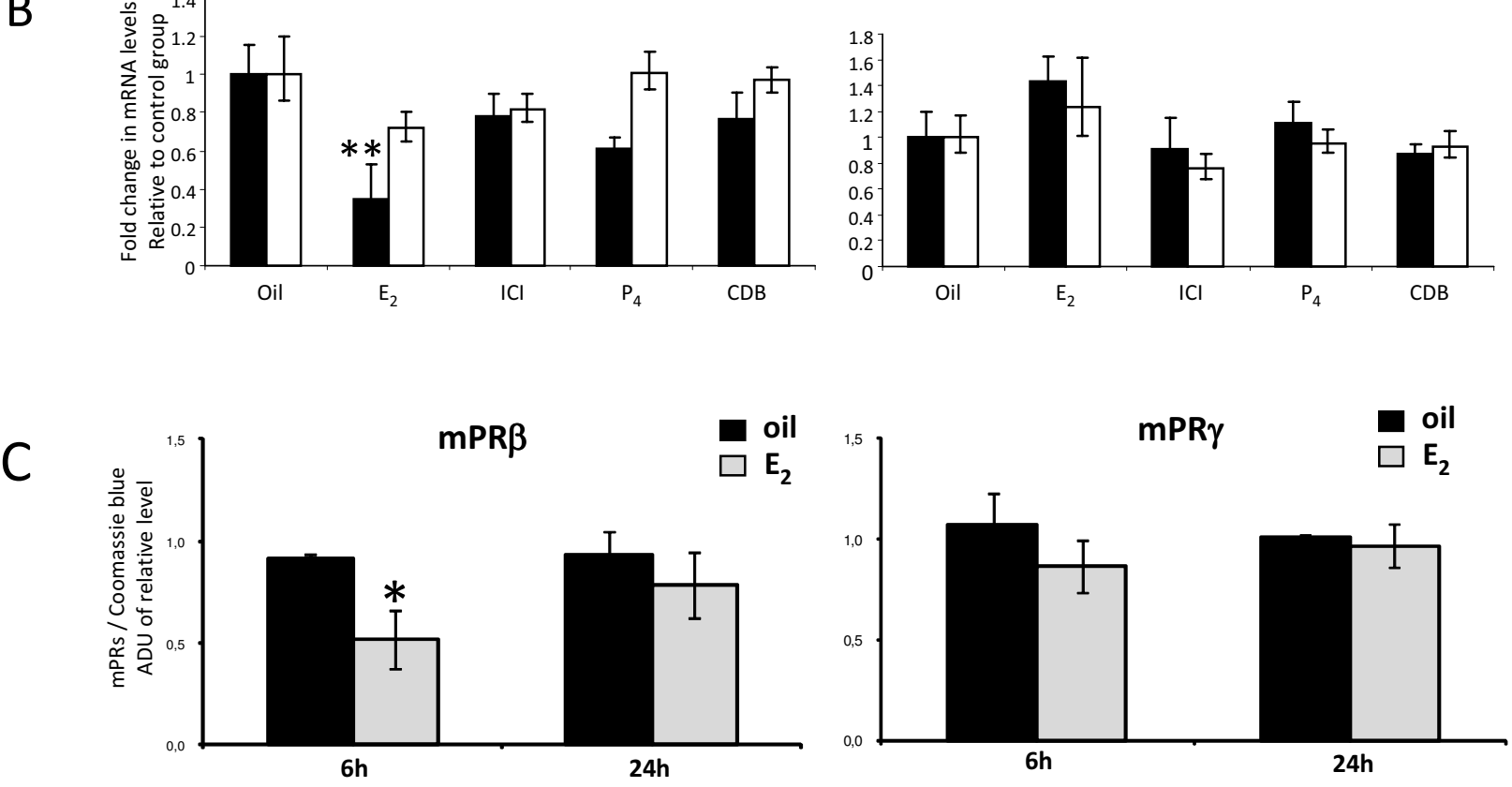

Figure 3

Steroid-dependent regulation of $\mathrm{mPR} \beta$ mRNA and $\mathrm{mPR} \gamma \mathrm{mRNA}$ (A and $B$ ) and protein (C) in the fallopian tube of immature female mice. Mouse ovary was included as a positive control in (A). Twenty-one-day-old female mice received an injection of $\mathrm{E}_{2}, \mathrm{P}_{4}$, the estrogen antagonist $\mathrm{ICI} 182,780$, the progesterone antagonist CDB29|4 or oil and sampled two or six hours later. The levels of mRNA are normalized to the endogenous control (GAPDH) and expressed in relative numbers to the control group as means \pm SEM of five independent observations (B) whereas protein levels are presented as mean \pm SEM of three independent pools, each consisting of tissue from ten mice (C). Groups differing significantly from the control group are indicated by asterisks ( $* *$ for $P<0.01$ and $*$ for $P<0.05$ ) 


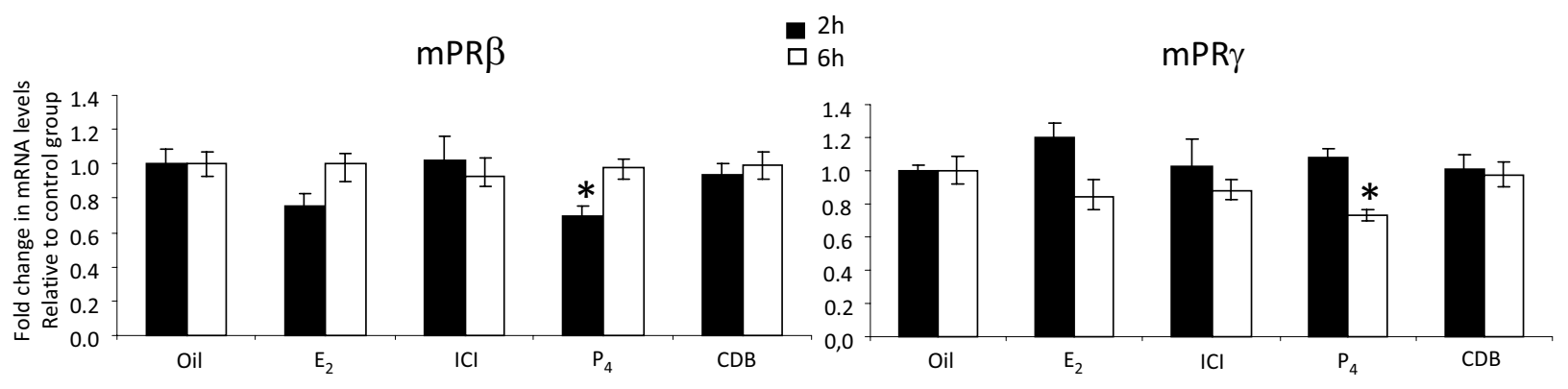

\section{Figure 4}

Steroid-dependent regulation of $\mathrm{mPR} \beta$ and $\gamma$ in fallopian tubes of eCG-primed, immature mice. Forty-eight hours after eCG injection, the mice received an injection of $E_{2}, P_{4}$, the estrogen antagonist ICI I82.780, the progesterone antagonist CDB2914 or oil and were sampled two or six hours later. The levels of the target genes are normalized to the endogenous controls (GAPDH) and presented relative to the control group. Values are presented as mean \pm SEM of five independent observations. The significance is shown as $* \mathrm{P}<0.05$ compared to the control group.

reticulum $[35,40,43,53]$. The transcript for $\operatorname{mPR} \beta$ has endoplasmatic reticulum export and endocytosis internalization motifs, which is in agreement with a potential intracellular localization $[40,54]$. It is important to stress that steroids easily pass the plasma membrane, thus the ligand(s) for mPR $\beta$ could quite possibly reach the receptor irrespective of its cellular localization.

Within the fallopian tube of mice and women, both $\operatorname{mPR} \beta$ and $\gamma$ are expressed exclusively in the ciliary epithelial cells. We previously reported that $\mathrm{mPR} \gamma$ was associated with the apical membrane at the base of the cilia of these cells [20]. Here, we show that $\mathrm{mPR} \beta$ is expressed on the same cells, but in contrast to $\mathrm{mPR} \gamma$, the receptors are found on the cilia themselves. The close association of both receptors with the cilia suggests an involvement in the regulation of ciliary activity by $\mathrm{P}_{4}$. In the cow, $\mathrm{P}_{4}$ decreases ciliary beat frequency within 15 minutes, and the effect cannot be blocked by a nuclear $\mathrm{P}_{4}$ receptor antagonist [9]. The co-occurrence of both receptors in the same cells also provides a possibility for a cooperative role. Cooperative roles for different mPR subtypes have been demonstrated previously in the induction of oocyte maturation in fish and in the regulation of PGR transactivation in human myometrial cells $[33,55]$. Interestingly, recent studies indicate the stimulatory effects of progestins on flagella activity and motility of fish and human sperm are mediated through a mPR subtype, $\operatorname{mPR} \alpha[56,57]$. A clear relationship between the abundance of the mPR protein on sperm membranes and sperm motility has been observed both in fish and humans $[56,57]$. Taken together the results suggest a possible widespread involvement of mPRs as intermediaries in progesterone modulation of the activities of ciliated and flagellated cells.
The classical PGR is also expressed in the fallopian tube; however, there is somewhat conflicting data regarding its distribution $[45,46,58]$. In the mouse, immunostaining for PGR was reported in the nuclei of luminal epithelial, stroma and smooth muscle cells [46,58], whereas in women the staining for PGR was restricted to the nuclei of epithelial and stromal cells [59]. In another study, no immunostaining was found for the classical PGR in the nuclei of any cell type in the mouse fallopian tube, whereas an intense staining was demonstrated in cilia proper [45], quite similar to the staining for $\operatorname{mPR} \beta$ reported here. In this context, it may be stressed that there are no apparent sequence similarities between the classical PGR and mPR $\beta$, thus little risk for one antibody to have high affinity for the other receptor. Several studies report a possible non-genomic, rapid signaling of $\mathrm{P}_{4}$ through PGR in different cell types [23,33,60]. Also, a plasma membrane localization of the classical PGR has also been suggested $[14,61,62]$. Together, this suggests that the ciliated cells of the fallopian tubes are equipped with a suite of $\mathrm{P}_{4}$ receptors, which all could be involved in controlling the beating of the cilia or possibly being involved in feedback systems by controlling receptor expression.

There is accumulating evidence that the family of mPRs $(\alpha, \beta$ and $\gamma$ ) act as receptors. Criteria, supporting a receptor function of the mPRs include information on plausible structure, tissue specificity, sub-cellular localization, steroid binding, signal transduction, hormonal regulation and biological relevance [12,29]. Although the aim of the present study has not been to scrutinize the classification of the mPRs as receptors, the generated data adds to the body of observations supporting such a role. One impor- 

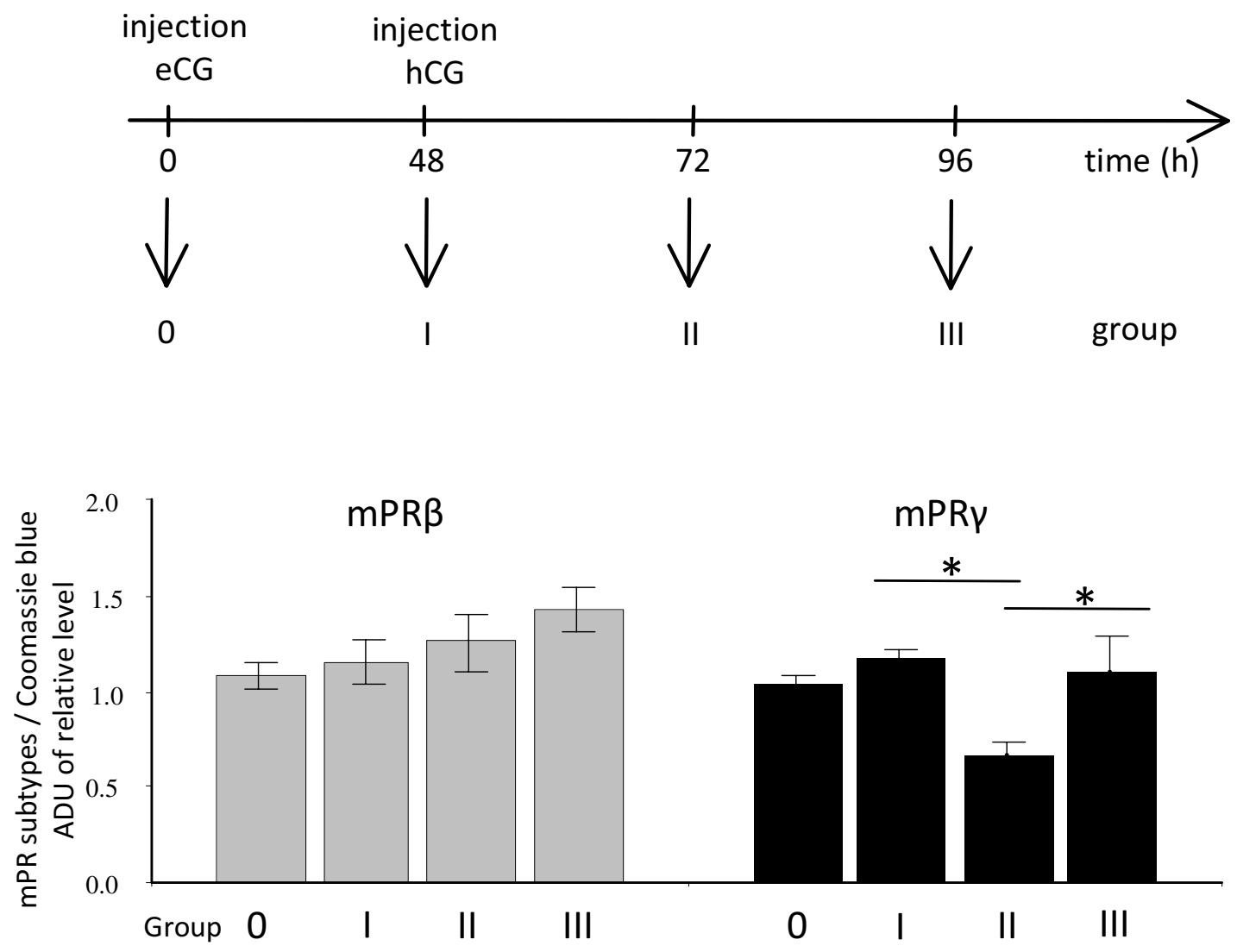

\section{Figure 5}

Expression of $\mathrm{mPR} \beta$ and $\gamma$ in fallopian tubes of mice induced to ovulate by injections of eCG (0 h) and hCG (48 h). Mice were sampled at times 0, 48, 72 and 96 hours post eCG-injection and analyzed by Western blotting. Samples from ten mice were pooled and the values are presented as mean \pm SEM of three independent pools for each group. All groups were compared with each other, applying Bonferroni's post-hoc test. The statistical significance is shown as $* P<0.05$.

tant observation is the plasma-membrane-association of $\operatorname{mPR} \beta$ and $\mathrm{mPR} \gamma$ on the ciliary cells, i.e. a plausible subcellular localization. Also, the location of $\mathrm{mPR} \beta$ on cilia of the fallopian tube, a cell-type known to respond rapidly within minutes to $\mathrm{P}_{4}$, is coherent with a receptor-role of $\mathrm{mPR} \beta$ and $\mathrm{mPR} \gamma$. Furthermore, treatment with exogenous $\mathrm{P}_{4}$ down-regulates both $\mathrm{mPR} \beta$ and $\mathrm{mPR} \gamma$ in gonadotropinprimed female mice within a few hours in the mouse fallopian tube. Indeed, it is very common that steroid receptors are regulated by their own ligand [29,30]. The functional fish progestin 17, 20 $\beta$-dihydroxy-4-pregnen-3one $(17,20 \beta$-DHP) down-regulates mPR $\beta$ mRNA in the ovary of the channel catfish [63]. In human myometrial cells, however, $\mathrm{P}_{4}$ does not affect the expression of $\mathrm{mPR} \beta$ [33]. We could only demonstrate a down-regulation by $\mathrm{P}_{4}$ in gonadotropin-primed mice, but not in immature mice. Thus, it appears that the regulation of mPRs by $\mathrm{P}_{4}$ differs between species, tissues and developmental stages.
The regulation of $\mathrm{mPR} \beta$ and $\mathrm{mPR} \gamma$ by exogenous $\mathrm{P}_{4}$ could be mediated via a direct stimulation of $\mathrm{P}_{4}$ receptors on the cililary cells, or for example by modulating the release of gonadotropins. Receptors for FSH in the fallopian tube have been reported, but their physiological function in this organ is yet unknown [64]. In estrogen-primed, castrated rats $\mathrm{P}_{4}$ induces the release of both FSH and LH [65]. This model resembles the eCG-injected immature mouse model where the eCG injection induces endogenous estrogen production. We could demonstrate a regulation of both $\mathrm{mPR} \beta$ and $\mathrm{mPR} \gamma$ by $\mathrm{P}_{4}$ in mice primed with eCG, but not in immature mice. This observation would be coherent with $\mathrm{P}_{4}$ regulating the mPRs via a hypothalamic/ pituitary action and a stimulated gonadotropin secretion, although this hypothesis needs to be further tested. There was a similar trend of a reduced expression of both $\mathrm{mPR} \beta$ and $\mathrm{mPR} \gamma$ in the estrogen-treated eCG-primed mice, consistent with an expected feedback on the gonadotropin 

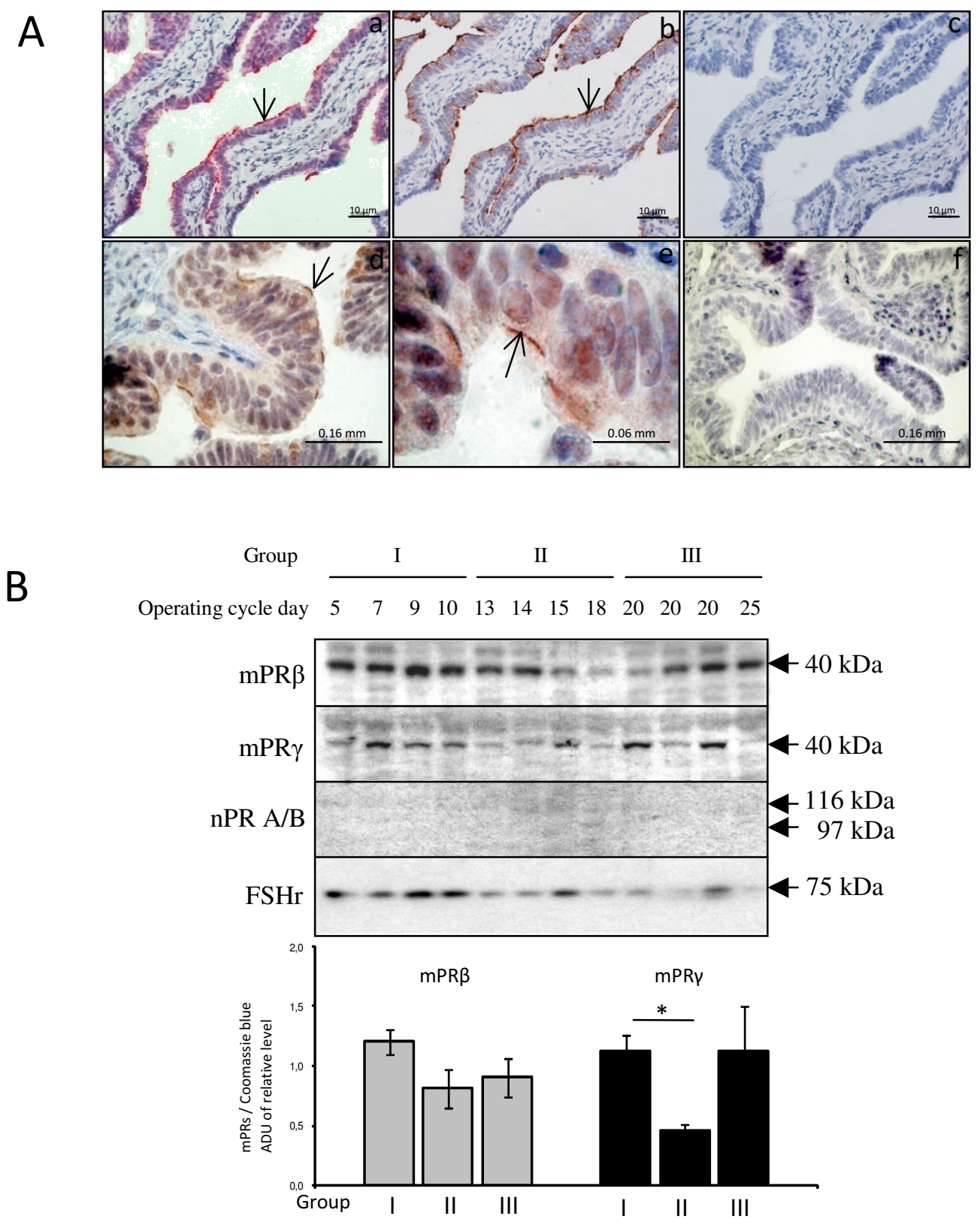

\section{Figure 6}

Localization (A) and regulation (B) of $\mathrm{mPR} \beta$ and $\gamma$ in the human fallopian tube during the normal reproductive cycle. The expression of $\operatorname{mPR} \beta(\mathbf{A}, \mathbf{a}), \beta$-tubulin $(\mathbf{A}, \mathbf{b})$ and $\operatorname{mPR} \gamma(\mathbf{A}, \mathbf{d}-\mathbf{e})$ are visualized by immunohistochemistry using specific antibodies. Subpanels $\mathbf{c}$ and $\mathbf{f}$ are control sections where the primary antibody was omitted. Another membrane bound protein, the FSH receptor (FSH) and the nuclear progesterone receptors were also analyzed to confirm that the sample preparation indeed contained membrane proteins. Sampled were obtained from patients in the follicular (group I), periovulatory (group II) and the luteal (group III) phase of the menstrual cycle. Protein levels of the mPRs are presented in the bar graph as arbitrary densiometric values normalized to whole protein in Coomassie blue staining. Values are presented as mean \pm SEM of four independent observations. For $\mathrm{mPR} \gamma$, assumptions for the general linear model was not met despite transformation of data (unequal variances), thus three independent t-tests (allowing unequal variances) were applied to compare stages I, II and III followed by a Bonferroni correction for multiple comparisons. The statistical significance is shown as $* \mathrm{P}<0.05$. 
release, but the effect was not statistically significant. On the other hand, $\mathrm{E}_{2}$ rapidly and significantly reduced the expression of mPR $\beta$, but not mPR $\gamma$ in the immature mouse model, clearly suggesting a gonadotropin-independent regulation. Tentative $\mathrm{E}_{2}$ and $\mathrm{P}_{4}$ response elements have been identified upstream from both the MPR $\beta$ and $\mathrm{mPR} \gamma$ genes [34], suggesting the possibility of a direct effect mediated via the classical steroid receptors. Direct regulation in vitro of $\mathrm{mPRs}$ by $\mathrm{P}_{4}$ and other progestin hormones has also been demonstrated previously in human myocytes and teleost ovaries $[29,33]$. As the travelling cumulus complex actively produces and releases steroids [15-18], the epithelium of the fallopian tube probably encounters higher steroid levels for a brief time period than do most cells in the body. Thus, it is possible that it is not the circulating steroids that are most important for regulating $\mathrm{MPR}$ expression in the fallopian tube, but rather steroids produced inside the fallopian tube. Indeed, the activation of sperm swimming by $\mathrm{P}_{4}$ is thought to be due to a gradient of locally produced $\mathrm{P}_{4}$ as the spermatozoa approaches the ovum inside the fallopian tube [66]. Notably, there is no intra-tubal steroid production in either the immature or the eCG model.

Access to samples from women undergoing tubal ligations at different time points in their menstrual cycles allowed us to start addressing the physiological regulation of mPRs in the human fallopian tube. Both $\mathrm{mPR} \beta$ and $\mathrm{mPR} \gamma$ are expressed on the ciliated cells of the human fallopian tube, similar to their location in mice. Interestingly, the expression of $\mathrm{mPR} \gamma$ was lower in women sampled close to mid cycle, i.e., around the time of ovulation, whereas there was no clear regulation of $\operatorname{mPR} \beta$. The general pattern of a down-regulation of $\mathrm{mPR} \gamma$ and a more stable expression of $\mathrm{mPR} \beta$ was also observed in mice induced to ovulate via two injections with gonadotropins. This pattern suggests that there are commonalities between the regulation of mPRs in the fallopian tube of mice and women, adding confidence to the use of mice as a human model in this context. The lack of apparent regulation of mPR $\beta$ in both ovulating mice and women may be somewhat difficult to interpret in relation to the results from the steroid injections, as there indeed are marked variations in the circulating steroid levels before and after ovulation in both species. Possibly, more frequent sampling could have revealed variations in the receptor expression.

\section{Conclusion}

In conclusion, we have demonstrated the presence of $\operatorname{mPR} \beta$ and $\gamma$ in ciliated cells of the fallopian tube of mice and women and the regulation of these receptors by $\mathrm{P}_{4}$ and/or $E_{2}$. These observations further strengthen the role of the ciliated cells of the fallopian tube as important physiological targets for $\mathrm{P}_{4}$. Taken together, our results support the hypothesis of an involvement of the mPRs in $\mathrm{P}_{4}$-regulated gamete transport in mammals.

\section{Competing interests}

The authors declare that they have no competing interests.

\section{Authors' contributions}

MN and DGJL conceived and designed the study, interpreted the results and drafted the manuscript. MN performed the sampling of the mice, carried out the RNA and protein preparations and conducted the Western blot analysis. BW performed the Taqman analysis and immunohistochemistry analysis. PT provided the specific antibody against mPR $\beta$ used in this study and gave suggestions and inputs on the drafts of the manuscript. ATK provided the clinical specimens. HB participated in the design of the study and the interpretation of the results and commented on the draft manuscript. All authors read and approved the final manuscript.

\section{Acknowledgements}

This work was supported by grants from Swedish Research Council (VR Medicine) and the Swedish Research Council for Environment, Agricultural Sciences and Spatial Planning (FORMAS) to D.G. J. Larsson and the Scientific Foundation of Emil och Maria Palm, Rådman och Fru Ernst Colliander to M. Nutu. We acknowledge the Centre for Cellular Imaging at the University of Gothenburg for the use of imaging equipment and for the support from the staff. We are also thankful to Dr. Ruijin Shao for providing valuable inputs in designing the study and for human data analysis.

\section{References}

I. Croxatto HB, Ortiz ME: Egg transport in the fallopian tube. Gynecol Invest 1975, 6(34):2 15-225.

2. Halbert SA, Tam PY, Blandau RJ: Egg transport in the rabbit oviduct: the roles of cilia and muscle. Science 1976, I 1 I(423 I): 1052-1053.

3. Halbert SA, Becker DR, Szal SE: Ovum transport in the rat oviductal ampulla in the absence of muscle contractility. Biol Reprod 1989, 40(6): I|31-1|36.

4. Critoph FN, Dennis KJ: Ciliary activity in the human oviduct. Obstet Gynecol Surv 1977, 32(7):602-603.

5. Lyons RA, Djahanbakhch O, Mahmood T, Saridogan E, Sattar S, Sheaff MT, Naftalin AA, Chenoy R: Fallopian tube ciliary beat frequency in relation to the stage of menstrual cycle and anatomical site. Hum Reprod 2002, I 7(3):584-588.

6. Ortiz ME, Villalon M, Croxatto HB: Ovum transport and fertility following postovulatory treatment with estradiol in rats. Biol Reprod 1979, 21 (5): II63-1167.

7. Orihuela PA, Ortiz ME, Croxatto HB: Sperm migration into and through the oviduct following artificial insemination at different stages of the estrous cycle in the rat. Biol Reprod 1999, 60(4):908-913.

8. Fuentealba B, Nieto M, Croxatto HB: Progesterone abbreviates the nuclear retention of estrogen receptor in the rat oviduct and counteracts estrogen action on egg transport. Biol Reprod 1988, 38(I):63-69.

9. Wessel T, Schuchter $U$, Walt H: Ciliary motility in bovine oviducts for sensing rapid non-genomic reactions upon exposure to progesterone. Horm Metab Res 2004, 36(3): I36-I4I.

10. Paltieli Y, Weichselbaum A, Hoffman N, Eibschitz I, Kam Z: Laser scattering instrument for real time in-vivo measurement of ciliary activity in human fallopian tubes. Hum Reprod 1995, I0(7): $1638-164 \mid$.

II. Mahmood T, Saridogan E, Smutna S, Habib AM, Djahanbakhch O: The effect of ovarian steroids on epithelial ciliary beat fre- 
quency in the human Fallopian tube. Hum Reprod 1998, I 3(I I):299|-2994.

12. Thomas $P$ : Characteristics of membrane progestin receptor alpha (mPRalpha) and progesterone membrane receptor component I (PGMRCI) and their roles in mediating rapid progestin actions. Front Neuroendocrinol 2008, 29(2):292-3I2.

13. Teves ME, Barbano F, Guidobaldi HA, Sanchez R, Miska W, Giojalas LC: Progesterone at the picomolar range is a chemoattractant for mammalian spermatozoa. Fertil Steril 2006, 86(3):745-749.

14. Sabeur K, Edwards DP, Meizel S: Human sperm plasma membrane progesterone receptor(s) and the acrosome reaction. Biol Reprod 1996, 54(5):993-100I.

15. Chian RC, Ao A, Clarke HJ, Tulandi T, Tan SL: Production of steroids from human cumulus cells treated with different concentrations of gonadotropins during culture in vitro. Fertil Steril I999, 7 I (I):6I-66.

16. Bar-Ami S, Gitay-Goren H, Brandes JM: Different morphological and steroidogenic patterns in oocyte/cumulus-corona cell complexes aspirated at in vitro fertilization. Biol Reprod 1989, 4I(4):76I-770.

17. Guidobaldi HA, Teves ME, Unates DR, Anastasia A, Giojalas LC: Progesterone from the cumulus cells is the sperm chemoattractant secreted by the rabbit oocyte cumulus complex. PLOS ONE 2008, 3(8):e3040.

18. Vanderhyden BC, Tonary AM: Differential regulation of progesterone and estradiol production by mouse cumulus and mural granulosa cells by $A$ factor(s) secreted by the oocyte. Biol Reprod 1995, 53(6): 1243-1250.

19. Yamashita Y, Shimada M, Okazaki T, Maeda T, Terada T: Production of progesterone from de novo-synthesized cholesterol in cumulus cells and its physiological role during meiotic resumption of porcine oocytes. Biol Reprod 2003, 68(4): I193-1198.

20. Nutu M, Weijdegard B, Thomas P, Bergh C, Thurin-Kjellberg A, Pang $Y$, Billig $H$, Larsson DG: Membrane progesterone receptor gamma: tissue distribution and expression in ciliated cells in the fallopian tube. Mol Reprod Dev 2007, 74(7):843-850.

21. Park OK, Mayo KE: Transient expression of progesterone receptor messenger RNA in ovarian granulosa cells after the preovulatory luteinizing hormone surge. Mol Endocrinol I991, 5(7):967-978.

22. Gava N, Clarke CL, Byth K, Arnett-Mansfield RL, deFazio A: Expression of progesterone receptors $A$ and $B$ in the mouse ovary during the estrous cycle. Endocrinology 2004, I45(7):3487-3494.

23. Boonyaratanakornkit V, McGowan E, Sherman L, Mancini MA, Cheskis BJ, Edwards DP: The role of extranuclear signaling actions of progesterone receptor in mediating progesterone regulation of gene expression and the cell cycle. Mol Endocrinol 2007, 2 I (2):359-375.

24. Park-Sarge OK, Parmer TG, Gu Y, Gibori G: Does the rat corpus luteum express the progesterone receptor gene? Endocrinology 1995, I36(4): 1537-1543.

25. Bar J, Lahav J, Hod M, Ben-Rafael Z, Weinberger I, Brosens J: Regulation of platelet aggregation and adenosine triphosphate release in vitro by 17 beta-estradiol and medroxyprogesterone acetate in postmenopausal women. Thromb Haemost 2000 , 84(4):695-700.

26. Frye CA, Sumida K, Lydon JP, O'Malley BW, Pfaff DW: Mid-aged and aged wild-type and progestin receptor knockout (PRKO) mice demonstrate rapid progesterone and 3alpha,5alpha-THP-facilitated lordosis. Psychopharmacology (Berl) 2006, I85(4):423-432.

27. Zhu Y, Hanna RN, Schaaf MJ, Spaink HP, Thomas P: Candidates for membrane progestin receptors past approaches and future challenges. Comp Biochem Physiol C Toxicol Pharmacol 2008, I 48(4):38|-389.

28. Zhu Y, Bond J, Thomas P: Identification, classification, and partial characterization of genes in humans and other vertebrates homologous to a fish membrane progestin receptor. Proc Natl Acad Sci USA 2003, 100(5):2237-2242.

29. Zhu Y, Rice CD, Pang Y, Pace M, Thomas P: Cloning, expression, and characterization of a membrane progestin receptor and evidence it is an intermediary in meiotic maturation of fish oocytes. Proc Natl Acad Sci USA 2003, I 00(5):223I-2236.
30. Smith JL, Kupchak BR, Garitaonandia I, Hoang LK, Maina AS, Regalla LM, Lyons TJ: Heterologous expression of human mPRalpha, mPRbeta and mPRgamma in yeast confirms their ability to function as membrane progesterone receptors. Steroids 2008, 73(II): II60-II73.

3I. Fernandes MS, Pierron V, Michalovich D, Astle S, Thornton S, Peltoketo H, Lam EW, Gellersen B, Huhtaniemi I, Allen J, Brosens J]: Regulated expression of putative membrane progestin receptor homologues in human endometrium and gestational tissues. J Endocrinol 2005, I87(I):89-I0I.

32. Ashley RL, Clay CM, Farmerie TA, Niswender GD, Nett TM: Cloning and characterization of an ovine intracellular seven transmembrane receptor for progesterone that mediates calcium mobilization. Endocrinology 2006, I47(9):4|5|-4I59.

33. Karteris E, Zervou S, Pang Y, Dong J, Hillhouse EW, Randeva HS, Thomas $P$ : Progesterone signaling in human myometrium through two novel membrane $\mathbf{G}$ protein-coupled receptors: potential role in functional progesterone withdrawal at term. Mol Endocrinol 2006, 20(7):1519-1534.

34. Kazeto Y, Goto-Kazeto R, Thomas P, Trant JM: Molecular characterization of three forms of putative membrane-bound progestin receptors and their tissue-distribution in channel catfish, Ictalurus punctatus. J Mol Endocrinol 2005, 34(3):78I-79|

35. Krietsch T, Fernandes MS, Kero J, Losel R, Heyens M, Lam EW, Huhtaniemi I, Brosens J], Gellersen B: Human homologs of the putative G protein-coupled membrane progestin receptors (mPRalpha, beta, and gamma) localize to the endoplasmic reticulum and are not activated by progesterone. Mol Endocrinol 2006, 20(I 2):3|46-3164.

36. Cai Z, Stocco C: Expression and regulation of progestin membrane receptors in the rat corpus luteum. Endocrinology 2005, I 46( ( 2):5522-5532.

37. Hanna R, Pang Y, Thomas P, Zhu Y: Cell-surface expression, progestin binding, and rapid nongenomic signaling of zebrafish membrane progestin receptors alpha and beta in transfected cells. J Endocrinol 2006, I 90(2):247-260.

38. Josefsberg Ben-Yehoshua L, Lewellyn AL, Thomas P, Maller JL: The role of Xenopus membrane progesterone receptor beta in mediating the effect of progesterone on oocyte maturation. Mol Endocrinol 2007, 2 I (3):664-673.

39. Monkkonen KS, Aflatoonian R, Lee KF, Yeung WS, Tsao SW, Laitinen JT, Fazeli A: Hormonal regulation of Galphai2 and $m P R a l p h a$ in immortalized human oviductal cell line OE-E6/E7. Mol Hum Reprod 2007, 13(12):845-85 I.

40. Qiu HB, Lu SS, Ji KL, Song XM, Lu YQ, Zhang M, Lu KH: Membrane progestin receptor beta (mPR-beta): A protein related to cumulus expansion that is involved in in vitro maturation of pig cumulus-oocyte complexes. Steroids 2008, 73(14): 1416-1423.

4I. Thomas P, Dressing G, Pang Y, Berg H, Tubbs C, Benninghoff A, Doughty K: Progestin, estrogen and androgen G-protein coupled receptors in fish gonads. Steroids 2006, 7 I(4):3I0-3I6.

42. Thomas P, Pang Y, Dong J, Groenen P, Kelder J, de Vlieg J, Zhu Y, Tubbs C: Steroid and $G$ protein binding characteristics of the seatrout and human progestin membrane receptor alpha subtypes and their evolutionary origins. Endocrinology 2007, I48(2):705-7|8.

43. Romero-Sanchez M, Peiper SC, Evans B, Wang Z, Catasus L, Ribe A Prat J, Giri JG: Expression profile of heptahelical putative membrane progesterone receptors in epithelial ovarian tumors. Hum Pathol 2008, 39(7): 1026- 033.

44. Thomas P: Discoveryof a new family of membrane progesterone receptors in vertebrates and detection of the alpha and beta subtypes in mouse brain, testis and uterus. Med Chem Res 2004, I3(3/4):202-209.

45. Teilmann SC, Clement CA, Thorup J, Byskov AG, Christensen ST: Expression and localization of the progesterone receptor in mouse and human reproductive organs. J Endocrinol 2006, | 9 |(3):525-535.

46. Shao R, Weijdegard B, Ljungstrom K, Friberg A, Zhu C, Wang X, Zhu $Y$, Fernandez-Rodriguez J, Egecioglu E, Rung E, Billig $\mathrm{H}$ : Nuclear progesterone receptor $A$ and $B$ isoforms in mouse fallopian tube and uterus: implications for expression, regulation, and cellular function. Am J Physiol Endocrinol Metab 2006, 29 I(I):E59-72. 
47. Shao R, Weijdegard B, Fernandez-Rodriguez J, Egecioglu E, Zhu C, Andersson N, Thurin-Kjellberg A, Bergh C, Billig H: Ciliated epithelial-specific and regional-specific expression and regulation of the estrogen receptor-beta2 in the fallopian tubes of immature rats: a possible mechanism for estrogen-mediated transport process in vivo. Am J Physiol Endocrinol Metab 2007, 293(I):EI47-I58.

48. Walmer DK, Wrona MA, Hughes CL, Nelson KG: Lactoferrin expression in the mouse reproductive tract during the natural estrous cycle: correlation with circulating estradiol and progesterone. Endocrinology 1992, I 3 I (3): | 1458-1466.

49. Shao R, Nutu M, Weijdegard B, Egecioglu E, Fernandez-Rodriguez J, Tallet $E$, Goffin V, Ling C, Billig H: Differences in prolactin receptor (PRLR) in mouse and human fallopian tubes: evidence for multiple regulatory mechanisms controlling PRLR isoform expression in mice. Biol Reprod 2008, 79(4):748-757.

50. Fujii E, Mellon SH: Regulation of uterine gamma-aminobutyric acid(A) receptor subunit expression throughout pregnancy. Endocrinology 200I, I42(5): I770-1777.

5I. Dosiou C, Hamilton AE, Pang Y, Overgaard MT, Tulac S, Dong J, Thomas P, Giudice LC: Expression of membrane progesterone receptors on human $T$ lymphocytes and Jurkat cells and activation of G-proteins by progesterone. J Endocrinol 2008, 196(I):67-77.

52. Sleiter N, Pang Y, Park C, Horton TH, Dong J, Thomas P, Levine JE: Progesterone receptor A (PRA) and PRB-independent effects of progesterone on gonadotropin-releasing hormone release. Endocrinology 2009, I 50(8):3833-3844.

53. Lemale J, Bloch-Faure M, Grimont A, El Abida B, Imbert-Teboul M, Crambert G: Membrane progestin receptors alpha and gamma in renal epithelium. Biochim Biophys Acta 2008, 1783( ( 2):2234-2240.

54. Jackson MR, Nilsson T, Peterson PA: Identification of a consensus motif for retention of transmembrane proteins in the endoplasmic reticulum. EMBO J 1990, 9(10):3153-3162.

55. Thomas $P$, Pang $Y$, Zhu Y, Detweiler C, Doughty K: Multiple rapid progestin actions and progestin membrane receptor subtypes in fish. Steroids 2004, 69(89):567-573.

56. Thomas P, Tubbs C, Garry VF: Progestin functions in vertebrate gametes mediated by membrane progestin receptors (mPRs): Identification of mPRalpha on human sperm and its association with sperm motility. Steroids 2009, 74(7):6|4-62I.

57. Tubbs $C$, Thomas P: Progestin signaling through an olfactory $\mathbf{G}$ protein and membrane progestin receptor-alpha in Atlantic croaker sperm: potential role in induction of sperm hypermotility. Endocrinology 2009, I 50 (I):473-484.

58. Okada A, Ohta Y, Inoue S, Hiroi H, Muramatsu M, Iguchi T: Expression of estrogen, progesterone and androgen receptors in the oviduct of developing, cycling and pre-implantation rats. J Mol Endocrinol 2003, 30(3):301-315.

59. Amso NN, Crow J, Shaw RW: Comparative immunohistochemical study of oestrogen and progesterone receptors in the fallopian tube and uterus at different stages of the menstrual cycle and the menopause. Hum Reprod 1994, 9(6): 1027-1037.

60. Boonyaratanakornkit V, Scott MP, Ribon V, Sherman L, Anderson SM, Maller JL, Miller WT, Edwards DP: Progesterone receptor contains a proline-rich motif that directly interacts with $\mathrm{SH}_{3}$ domains and activates c-Src family tyrosine kinases. Mol Cell 200I, 8(2):269-280

61. Liu Z, Patino R: High-affinity binding of progesterone to the plasma membrane of Xenopus oocytes: characteristics of binding and hormonal and developmental control. Biol Reprod 1993, 49(5):980-988.

62. Flores-Herrera H, Diaz-Cervantes P, De la Mora G, Zaga-Clavellina $V$, Uribe-Salas F, Castro I: A possible role of progesterone receptor in mouse oocyte in vitro fertilization regulated by norethisterone and its reduced metabolite. Contraception 2008, 78(6):507-5। 2 .

63. Kazeto Y, Goto-Kazeto R, Trant JM: Membrane-bound progestin receptors in channel catfish and zebrafish ovary: changes in gene expression associated with the reproductive cycles and hormonal reagents. Gen Comp Endocrinol 2005, I 42( I 2):204-2I I.

64. Zheng W, Magid MS, Kramer EE, Chen YT: Follicle-stimulating hormone receptor is expressed in human ovarian surface epithelium and fallopian tube. Am J Pathol 1996, I48(I):47-53.
65. Caligaris L, Astrada JJ, Taleisnik S: Biphasic effect of progesterone on the release of gonadotropin in rats. Endocrinology 197I, 89(2):33I-337.

66. Harper CV, Barratt CL, Publicover SJ: Stimulation of human spermatozoa with progesterone gradients to simulate approach to the oocyte. Induction of $[\mathrm{Ca}(2+)](i)$ oscillations and cyclical transitions in flagellar beating. J Biol Chem 2004, 279(44):463I5-46325.
Publish with Bio Med Central and every scientist can read your work free of charge

"BioMed Central will be the most significant development for disseminating the results of biomedical research in our lifetime. "

Sir Paul Nurse, Cancer Research UK

Your research papers will be:

- available free of charge to the entire biomedical community

- peer reviewed and published immediately upon acceptance

- cited in PubMed and archived on PubMed Central

- yours - you keep the copyright

Submit your manuscript here:

http://www.biomedcentral.com/info/publishing_adv.asp 